\title{
Biogenic fluxes in the Bransfield Strait: planktonic versus macroalgal sources
}

\author{
Gerd Liebezeit ${ }^{1}$ \& Bodo von Bodungen ${ }^{2}$ \\ ${ }^{1}$ Geologisch-Paläontologisches Institut, Bundesstraße 55, D-2000 Hamburg 13, Federal Republic of Germany \\ ${ }^{2}$ Institut für Meereskunde, Düsternbrooker Weg 20, D-2300 Kiel, Federal Republic of Germany
}

\begin{abstract}
Fluxes of organic carbon and nitrogen, total phosphorus, chlorophyll pigments, carbohydrates, amino acids and amino sugars were determined for a depth-series sediment trap experiment in November/December 1983 in the Bransfield Strait, Antarctic Peninsula. Absolute and/or relative increases of phosphorus, glucose and chlorophyll $b$ fluxes and decrease of $\beta$-alanine flux with depth suggest a second source of sedimenting organic material besides plankton. This is identified as originating from shallow water macroalgae. Quantification of this contribution shows increases from $37 \%$ at $539 \mathrm{~m}$ to $71 \%$ at $1835 \mathrm{~m}$. Comparison of corrected planktonic fluxes with values predicted by the empirical equation of Suess (1980) are in good agreement. Examination of carbohydrate spectra from Bransfield Strait surface sediments shows a macroalgal imprint to be present.
\end{abstract}

\section{INTRODUCTION}

Coastal and shelf sediments receive a considerable input of terrestrial organic matcriul in addition lo autochthonous matter (Berner 1982, Degens \& Ittekkot 1985). The latter may originate from primary, both planktonic and macrophytal, and secondary production. A distinction between these sources based on bulk chemical analysis of sediment trap samples is usually beset with difficulties unless specific biomarker compounds are used. Amino acids and carbohydrates which make up the majority of the particulate organic carbon flux in the world ocean (Ittekkot et al. $1984 a, b$, Lee \& Cronin 1984) are present in all sources of sedimenting organic matter, thus restricting the usefulness of these parameters to descriptive purposes.

It has, however, been suggested that compound ratios should be employed (Degens \& Mopper 1976, Cowle \& Hedges 1984), thereby exploiting differences in e.g. carbohydrate pool composition to elucidate contributions from different sources. Using this approach, Cowie \& Hedges (1984) were able to distinguish between terrigenous and marine organic matter in their sediment traps in Dabob Bay, Washington. Similarly, Liebezeit \& Ittekkot (unpubl.) identified a background flux of terrestrial material at $2600 \mathrm{~m}$ water depth in the Lofoten Basin. The interpretation of such data is somewhat simplified if one (or more) sources can be virtually excluded. Thus, in shallow waters of the Bransfield Strait, Antarctic, phyto- and zooplankton were the dominant producers of both suspended and sedimenting organic matter in the austral summer 1980 (von Bodungen et al. 1986). This was also clearly reflected in the amino acid and carbohydrate compositions (Liebezeit 1985, in press, Liebezeit \& Bölter 1986).

In this paper, we present data on the chemical composition of samples derived from a depth-series sediment trap array from the Bransfield Strait in November/December 1983. Based on these data an attempt is made to establish sources of sedimenting matter and to quantify their contributions.

\section{MATERIAL AND METHODS}

An array of 5 sediment traps was moored in King George Basin, eastern Bransfield Strait $\left(62^{\circ} 16.3^{\prime} \mathrm{S}\right.$, $57^{\circ} 22.8^{\prime} \mathrm{W}$ ), at a water depth of $1850 \mathrm{~m}$ from 27 November to 20 December 1983. Traps were suspended at 323, 539, 963, 1410 and $1835 \mathrm{~m}$. Funnelshaped Kiel-design traps (Zeitzschel et al. 1978) with a single collection jar were deployed. Chloroform was used for sample preservation. After retrieval, the trapped material was split, desalted by repeated washing with distilled water, and lyophilised. 
Carbon and nitrogen were determined with a Hewlett Packard $185 \mathrm{~B}$ CHN analyser. Total particulate phosphorus (TPP) was determined according to Grasshoff (1976).

Particle composition and intact phytoplankton cells were evaluated with an inverted microscope from a subsample preserved with buffered formalin. Phytoplankton carbon (PPC) was calculated from cell counts which were converted to cell and plasma volume, the latter being multiplied by 0.11 to obtain PPC (Edler 1979).

Chlorophyll pigments were determined on $90 \%$ aqueous acetone extracts and are given as chlorophyll a equivalents representing the sum of chlorophyll a and phaeopigments, calculated according to Lorenzen (1967). High performance liquid chromatography (HPLC) of these compounds was carried out according to Evershcd et al. (unpubl.) with fluorimetric detection (Liebezeit 1980) using dichloromethane/ methanol 9:1 (30 min RT) extracts. Additionally, pigment fluxes were obtained from absorption spectroscopical analysis of the latter extracts. For quantification, the $\alpha$-band at $665 \mathrm{~nm}$ was used. Results are expressed as chlorophyll a equivalents. The 2 total techniques generally showed good agreement (Table 1).

Table 1. Comparison between the Lorenzen (1967) equation and scanning absorption spectroscopy for total chlorophyll determination. Values in $\mathrm{mg}$ chlorophyll a equivalents $\mathrm{m}^{-2}$ $d^{-1}$

\begin{tabular}{|lccccc|}
\hline & \multicolumn{5}{c|}{ Depth (m) } \\
& 323 & 539 & 963 & 1410 & 1835 \\
\hline Lorenzen (1967) & 3.00 & 2.48 & 1.57 & 1.39 & 1.03 \\
Abs. spectr. & 3.55 & 2.86 & 1.66 & 1.38 & 0.96 \\
\hline
\end{tabular}

Due to the presence of acetic acid in the eluent used for HPLC, only phaeopigments could be determined. These were identified and quantified by comparison to an external standard run. Unknown compound concentrations are expressed in phaeophytin a equivalents.

Amino acids were analysed according to Lindroth \& Mopper (1979) after hydrolysis with $6 \mathrm{~N} \mathrm{HCl}$ at $110^{\circ} \mathrm{C}$ for $24 \mathrm{~h}$ under nitrogen. Sodium acetate/methanol $(0.05$ M) was employed as eluent system. Quantification was by comparison to an external standard run with $\alpha$ amino butyric acid as internal standard (Dawson \& Liebezeit 1983). Hexosamines are not separated from each other by this technique and are expressed in glucosamine equivalents. Concentrations are corrected for losses during hydrolysis by multiplying by a factor of 1.38 (Liebezeit unpubl.).

Monosaccharides were analysed by borate anion exchange chromatography after hydrolysis at $110^{\circ} \mathrm{C}$ for $3 \mathrm{~h}$ under nitrogen as described by Dawson \& Liebezeit (1983).

In sediment trap experiments with 2 parallel collection jars, von Bodungen et al. (1986) found variabilities for bulk parameters to be $<10 \%$. Similarly, variabilities for amino acid and carbohydrate determinations were $<12 \%$ whereas the value for chlorophyll HPLC was $<5 \%$. In the case of the 2 total pigment techniques, reproducibility of these standard methods was within generally accepted limits.

\section{RESULTS AND DISCUSSION}

\section{Bulk fluxes}

Total mass flux was relatively constant in the upper 3 traps and increased with depth (Table 2), Both POC and PON fluxes decreased with the exception of the $1410 \mathrm{~m}$ sample, whereas TPP increased towards $1410 \mathrm{~m}$ and stayed constant thereafter.

Table 2. Compound fluxes in the Bransfield Strait. All values in $\mathrm{mg} \mathrm{m} \mathrm{m}^{-2} \mathrm{~d}^{-1}$. POC: particulate organic carbon; PON: particulate organic nitrogen: TPP: total particulate phosphorus; AA-C: amino acid carbon; AS-C: amino sugar carbon; MS-C: monosaccharide carbon; CHL: chlorophyll pigments in chlorophyll a equivalents (see Table 1); PPC: phytoplankton carbon

\begin{tabular}{|c|c|c|c|c|c|}
\hline \multirow[t]{2}{*}{ Compound } & \multicolumn{5}{|c|}{ Depth (m) } \\
\hline & 323 & 539 & 963 & 1410 & 1835 \\
\hline Total flux & 3170.8 & 3289.7 & 3462.4 & 4923.4 & 5585.0 \\
\hline POC & 131.9 & 120.3 & 80.3 & 94.3 & 81.3 \\
\hline PON & 14.5 & 13.2 & 7.3 & 9.6 & 7.7 \\
\hline $\mathrm{TPP}$ & 0.9 & 1.3 & 2.4 & 4.0 & 4.1 \\
\hline$A A-C$ & 28.2 & 21.0 & 21.5 & 27.0 & 20.0 \\
\hline AS-C & 0.6 & 1.2 & 1.2 & 2.2 & 0.4 \\
\hline MS-C & 5.5 & 10.8 & 9.3 & 17.0 & 9.8 \\
\hline $\mathrm{CHL}$ & 3.5 & 2.9 & 1.7 & 1.4 & 1.0 \\
\hline PPC & 1.4 & 1.4 & $>0^{\circ}$ & $>0^{\circ}$ & $>0^{\circ}$ \\
\hline
\end{tabular}

Amino acid carbon (AA-C) and amino sugar carbon (AS-C) more or less paralleled the POC fluxes whereas monosaccharide carbon (MS-C) showed more variability (Table 2). Chlorophyll pigment (CHL) fluxes decreased constantly with depth.

Contributions to the characterised fraction of the POC pool increased towards $1410 \mathrm{~m}$ and then decreased. In all traps, relative AA-C contents are comparable to data from other sediment trap experiments (e.g. Wefer et al. 1982, Lee \& Cronin 1984, Liebezeit 


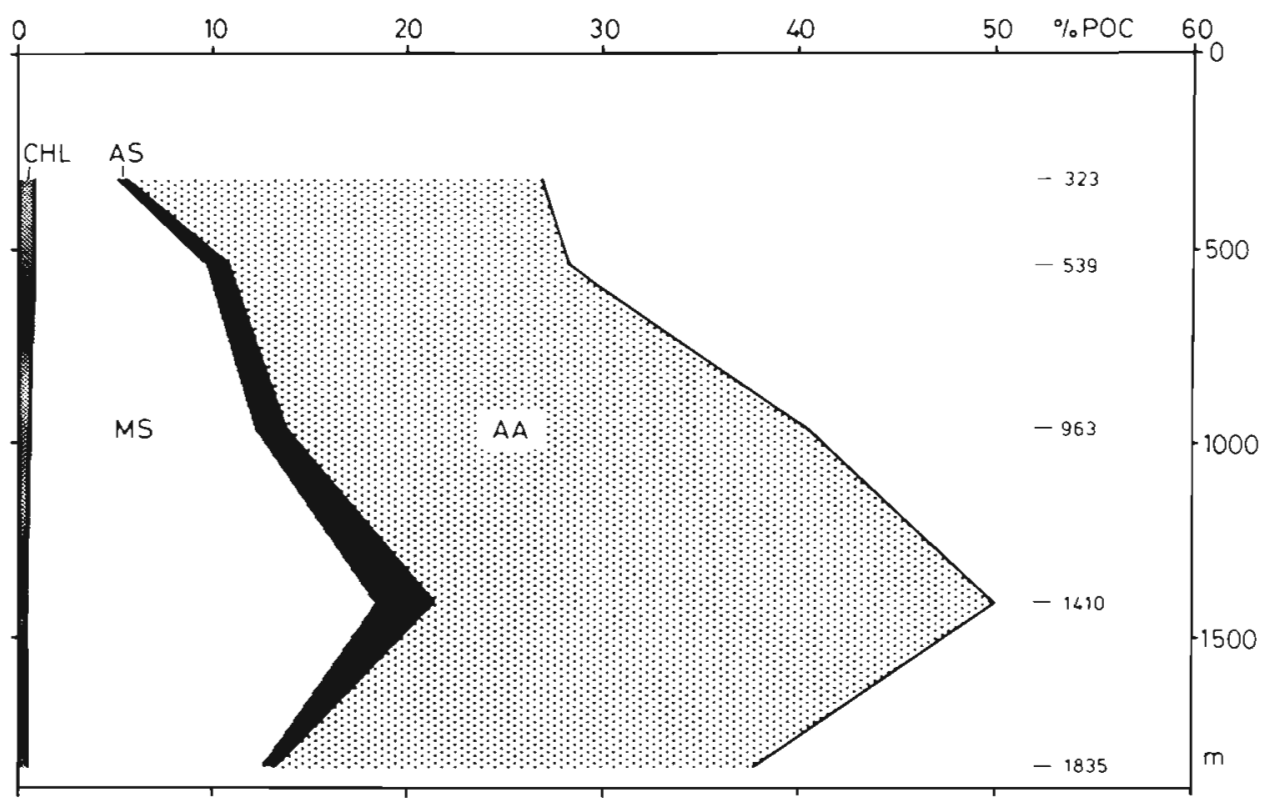

Fig. 1. Relative contributions of chlorophylls (CHL), monosaccharides (MS), amino sugars (AS) and amino acids (AA) to total carbon flux in Bransfield Strait

1985). Amino sugars closely followed the amino acid pattern (Fig. 1) whereas relative chlorophyll contents decreased constantly with depth.

Contributions of amino acid nitrogen to the total nitrogen pool increased from $32 \%$ at $323 \mathrm{~m}$ to $83 \%$ at $1835 \mathrm{~m}$ with the $963 \mathrm{~m}$ value being $104 \%$. Possible reasons for discrepancies between the 2 nitrogen assays have been discussed in detail by Liebezeil \& Bölter (1986).

The observed amino acid depth relation is quite uncommon. Generally, as a result of heterotrophic degradation, contributions of amino acids to both POC and PON decrease with depth, both in water column particulates (Liebezeit \& Bölter 1986) and sediment trap material (Lee \& Cronin 1984, Liebezeit 1985).

Carbohydrates showed values comparable to other flux data (Ittekkot et al. 1984a, b, Liebezeit \& Ittekkot unpubl.) only in the uppermost trap. In the deeper traps, sugar fluxes were significantly higher. In shortterm experiments with drifting sediment traps similarly high fluxes as in the 539 to $1835 \mathrm{~m}$ samples have been found at the bottom of the euphotic zone in the Bransfield Strait (Liebezeit in press). These were related to a high contribution of diatom aggregates with a considerable proportion of resting spores.

In the present experiments biogenic opal contributed $>60 \%$ of the total mass flux in the upper 2 traps whereas in the lower ones this contribution decreased to less than $25 \%$ (Gersonde \& Wefer 1986). Absolute fluxes decreased from about 2 to $1 \mathrm{~g} \mathrm{~m}^{-2} \mathrm{~d}^{-1}$ with depth.

Similarly, microscopic analysis of the trapped material showed the upper trap to be clearly dominated by krill faeces and flocculent detritus containing finely shredded diatom debris (von Bodungen 1986). In the 539 and $963 \mathrm{~m}$ traps intact faeces decreased together with the flocculent material whereas in the deepest traps krill faeces were not abundant and small, non-flocculent material made up the bulk of particles. in these samples, a strong admixture of resuspended lithogenic compounds such as quartz and clay minerals was observed by Gersonde \& Wefer (1987) thus explaining the increasing total flux with depth (Table 2).

Intact phytoplankton cells (PPC, Table 2) in the upper 2 traps were almost exclusively Thalassiosira antarctica. In the deeper traps only few cells containing mostly shrivelled plasma were found, these being mainly pennate diatoms. PPC was in all cases a negligible part of total flux (Table 2). Hence, the high carbohydrate contents of the trapped material are not due to high phytoplankton contributions. This, together with the unusual amino acid data suggests an additional mid to deep water source of sedimenting material.

Although some losses due to leaching by the fixing agent might have occurred, pigment fluxes are the highest reported so far in the literature. Lorenzen et al. (1983) found a mean flux of $0.15(0.07$ to 0.23$) \mathrm{mg}$ phaeopigments $\mathrm{m}^{-2} \mathrm{~d}^{-1}$ for the subarctic Pacific at deployment depths from 250 to $3000 \mathrm{~m}$. Average primary production of $494 \mathrm{mgC} \mathrm{m}^{-2} \mathrm{~d}^{-1}$ was, however, comparable to that of the Bransfield Strait in the austral summer 1983 (von Bodungen 1986). 
In the Panama Basin, total chlorophyll pigment flux was on the average $0.18 \mathrm{mg} \mathrm{m}^{-2} \mathrm{~d}^{-1}$ with a high value of 0.32 associated with the settling of the spring bloom (Cole et al. 1985). In coastal environments at $50 \mathrm{~m}$ water depth, pigment fluxes were generally higher and comparable to those found in the present experiments (Table 2; Staresinic 1980, Lorenzen et al. 1981).

It has been shown for Kiel Bight (Smetacek et al. 1984) that sedimentation of plankton blooms occurs in a matter of days which is also evident from chemical flux data (e.g. Peinert et al. 1982, Liebezeit et al. 1985). Thus, differences between the present pigment fluxes and those from other oceanic environments might simply reflect dilution of a short-term high flux due to a long sampling period. However, in the study of Lorenzen et al. (1983) the sampling time was only half that in the Bransfield Strait. Thus, from pigment fluxes it would appear that sedimentation here is more closely related to highly productive coastal environments than to oceanic ones. This might not necessarily hold true for the whole duration of optimum conditions for plankton growth, i.e. only for the period where grazing pressure is not too pronounced (von Bodungen et al. 1986).

\section{Bulk ratios}

Carbon to phosphorus and nitrogen to phosphorus ratios decreased consistently with depth (Table 3). This is quite different from the normally observed trends (e.g. von Bodungen 1975, Knauer et al. 1979, Wefer et al. 1982) where increasing values with depth (or time)
Table 3. C, N and P atomic ratios of sediment trap material

\begin{tabular}{|crrr|}
\hline Depth (m) & C:P & N:P & C:N \\
\hline 323 & 379 & 36 & 10.6 \\
539 & 238 & 22 & 10.6 \\
963 & 87 & 7 & 12.8 \\
1410 & 60 & 5 & 11.5 \\
1835 & 52 & 4 & 12.4 \\
\hline
\end{tabular}

indicate rapid remineralisation of organic phosphorus compounds. $\mathrm{C} / \mathrm{N}$ ratios, on the other hand, remain relatively constant with depth (Table 3 ). This would suggest that planktonic material, after an initial degradation through krill feeding, does not undergo any further decomposition. This is, however, not borne out by common experience (e.g. Lorenzen et al. 1983).

Knauer et al. (1979) reported oniy minor variations of both $\mathrm{C} / \mathrm{P}$ and $\mathrm{C} / \mathrm{N}$ ratios with depth under coastal upwelling conditions off California. The Antarctic ecosystem has, however, a plentiful supply of nutrients which are not limiting factors for production here (Sakshaug \& Holm-Hansen 1984). These data therefore also support an additional input of organic material rich in nitrogen and phosphorus.

Amino acid/monosaccharide (AA/MS) ratios have been used to assess protein degradation during vertical transport (Ittekkot et al. 1984a, b). During sedimentation of the bloom this ratio was high with a general tendency towards decreasing values with depth. In the Bransfield Strait samples, absolute amino acid fluxes

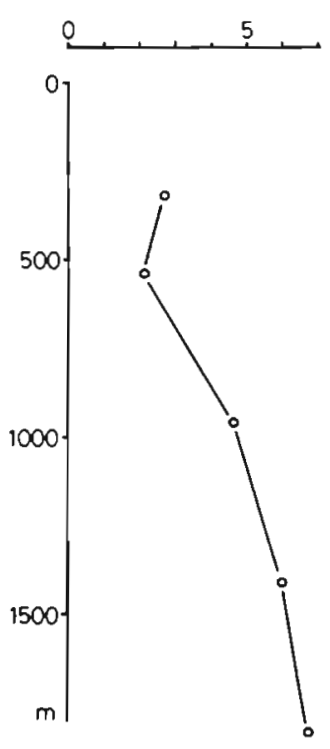

$A A-N / C H L$
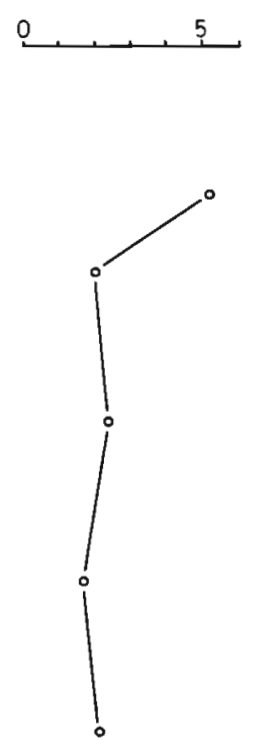

AA/MS
0

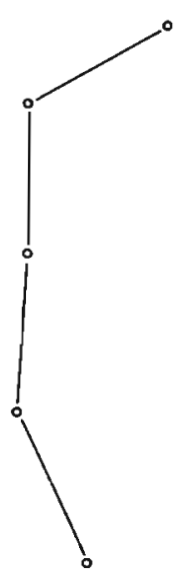

AA/AS
O

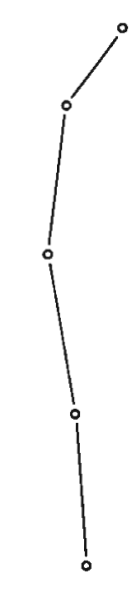

A SP/GLY
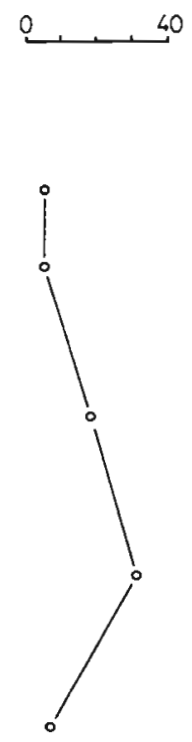

GLCIRIB

Fig. 2. Changes of compound ratios with depth. For details see text 
were relatively constant with depth (Table 2). The observed decrease in AA/MS ratios with depth (Fig. 2) is therefore the result of an increased carbohydrate flux.

In mesopelagic traps, Honjo et al. (1982) found up to $20 \%$ of the organic flux to be of zooplankton origin. For an assessment of contributions from this source, Ittekkot et al. (1984a, b) used amino acid/amino sugar (AA/AS) ratios. Although there is a pronounced decrease from the upper trap to the lower ones, values are generally $>20$ indicating that zooplankton remains do not contribute significantly to total organic flux. This is also supported by microscopic examination which showed exuviae or other identifiable parts to be negligible.

Both carbon/chlorophyl (POC/CHL) and amino acid nitrogen/chlorophyll (AA-N/CHL) ratios have been used to characterise the degradational status of sedimenting and suspended material in Antarctic waters (von Bodungen 1986, von Bodungen et al. 1986, Liebezeit \& Bölter 1986). POC/CHL ratios increased from 44 at $323 \mathrm{~m}$ to 79 at $1835 \mathrm{~m}$ while $\mathrm{AA}-\mathrm{N} / \mathrm{CHL}$ increased from 2.7 to 6.7 (Fig. 2). This range of ratios is also found in euphotic zone material (von Bodungen 1986, Liebezeit \& Bölter 1986). These values suggest no or only minor degradation of the trapped material with depth assuming a planktonic source only, thus lending support to the conclusions based on $\mathrm{C} / \mathrm{N}$ ratios.

\section{Amino acid fluxes}

The relative contributions of individual amino acids to the total pool are given in Table 4. Generally, aspartic and glutamic acids and glycine are the major compounds. In the upper 3 traps, $\beta$-alanine was present in considerable quantities also. The presence of this aspartic acid degradation product is commonly linked with bacterial activity on sinking material (Lee \& Cronin 1982).

In the upper traps krill faeces formed the dominant part of the organic flux. The occurrence of $\beta$-alanine suggests that faecal material, presumably due to its predigested nature, acts as a preferred site for bacterial degradation of particulate matter.

The aspartic acid/glycine ratio has been used to distinguish between siliceous and calcareous biogenic contributions (e.g. Ittekkot et al. 1984a, b). In the present study, this ratio is well above 1 indicating a major contribution of calcareous organisms (Fig. 2). There is a noticeable decrease with depth which would suggest increasing importance of siliceous plankters. This is in apparent contradiction to microscopic examinations and the data of Gersonde \& Wefer (1987) mentioned above.
Table 4. Composition of the characterised fraction of Bransfield Strait sediment trap material

\begin{tabular}{|c|c|c|c|c|c|}
\hline \multirow{2}{*}{ Compound } & \multicolumn{5}{|c|}{ Depth $(\mathrm{m})$} \\
\hline & 323 & 539 & 963 & 1410 & 1835 \\
\hline \multicolumn{6}{|l|}{ Amino acids (mol \%) } \\
\hline Alanine & 5.5 & 5.4 & 6.2 & 3.9 & 4.4 \\
\hline Glycine & 11.6 & 14.9 & 21.9 & 13.3 & 16.3 \\
\hline Isoleucine & 0.6 & 1.9 & 0.7 & 0.6 & 0.7 \\
\hline Leucine & 1.6 & 2.1 & 1.7 & 0.9 & 1.8 \\
\hline Phenylalanine & 1.3 & 2.1 & 1.2 & 0.9 & 1.4 \\
\hline Serine & 5.4 & 8.6 & 6.0 & 6.7 & 7.3 \\
\hline Threonine & 4.1 & 5.0 & 5.0 & 4.6 & 4.8 \\
\hline Tyrosine & 1.0 & 1.2 & 1.3 & 1.6 & 1.9 \\
\hline Valine & 0.5 & 0.8 & 1.5 & 1.6 & 1.0 \\
\hline Aspartic acid & 39.3 & 27.2 & 29.1 & 28.8 & 40.3 \\
\hline Glutamic acid & 14.4 & 15.5 & 12.0 & 33.7 & 14.4 \\
\hline Arginine & 0.9 & 2.1 & 0.7 & 0.1 & + \\
\hline Histidine & 4.1 & 7.3 & 6.5 & 2.7 & 3.9 \\
\hline Lysine & 0.3 & + & 0.7 & 0.4 & + \\
\hline$\beta$-alanine & 9.4 & 5.8 & 5.5 & 0.4 & 1.7 \\
\hline Total $\left(\mu \mathrm{mol} \mathrm{g}{ }^{-1}\right)$ & 192.1 & 109.3 & 136.0 & 112.6 & 75.8 \\
\hline \multicolumn{6}{|l|}{ Carbohydrates (mol \%) } \\
\hline Glucose & 31.0 & 27.5 & 32.0 & 43.7 & 28.3 \\
\hline Galactose & 8.2 & 9.1 & 5.8 & 5.4 & 9.3 \\
\hline Mannose & 10.3 & 8.1 & 8.5 & 4.3 & 8.3 \\
\hline Fructose & 29.7 & 19.0 & 36.1 & 33.0 & 24.4 \\
\hline Arabinose & 1.2 & 2.1 & 1.5 & 1.6 & 2.4 \\
\hline Ribose & 4.6 & 4.2 & 1.6 & 1.3 & 2.8 \\
\hline Xylose & 3.7 & 4.5 & 2.8 & 2.9 & 4.5 \\
\hline Fucose & 4.7 & 12.6 & 3.8 & 2.9 & 4.9 \\
\hline 2-deoxyribose & 3.5 & 0.9 & 2.0 & 1.6 & 1.7 \\
\hline Unknown ${ }^{*}$ & 3.2 & 11.1 & 4.7 & 3.1 & 11.4 \\
\hline Total $\left(\mu \mathrm{mol} \mathrm{g}{ }^{-1}\right)$ & 24.7 & 47.2 & 38.2 & 48.8 & 25.3 \\
\hline \multicolumn{6}{|l|}{ Pigments (wt \%) } \\
\hline Phaeophytin a & 19.5 & 16.5 & 25.3 & 36.9 & 35.5 \\
\hline Phaeophytin $b$ & 0.7 & 0.8 & 2.8 & 4.0 & 4.9 \\
\hline Acidic compounds" & 52.7 & 49.8 & 40.0 & 39.0 & 43.8 \\
\hline Unknown $\cdots$ & 28.1 & 32.9 & 31.9 & 19.6 & 15.8 \\
\hline Total $\left(\mathrm{mg} \mathrm{g}^{-1}\right)$ & 1.1 & 0.9 & 0.5 & 0.3 & 0.2 \\
\hline Hexosamines $\left(\mu \mathrm{mol} \mathrm{g}^{-1}\right)$ & 3.9 & 6.1 & 7.6 & 9.0 & 1.5 \\
\hline \multicolumn{6}{|c|}{$\begin{array}{l}\text { - Unknown compounds in 2-deoxyribose equivalents } \\
\text {.. Acidic compounds in phaephorbide a equivalents } \\
\text { Unknown compounds in phaeophytin a equivalents }\end{array}$} \\
\hline
\end{tabular}

\section{Carbohydrate fluxes}

The monosaccharide spectra of all samples are dominated by glucose and fructose (Table 4). Degens \& Mopper (1976) have suggested the use of the glucose/ ribose (GLC/RIB) ratio to distinguish between marine and terrestrial organic matter. Thus, the higher values in the lower traps would be indicative of a predominantly terrestrial origin or, to be more precise, to indicate the presence of significant quantities of cellulose. However, marine plankton can have GLC/RIB ratios as 
high as 120 when large amounts of reserve glucans are present (Liebezeit 1986). Therefore, this ratio does not appear to be a particularly suitable parameter for source identification in relatively fresh material.

Cowie \& Hedges (1984) have introduced the mannose/xylose ratio and the sum of ribose + fucose (wt $\%$ on a glucose free basis) for similar purposes. These values indicate for the former ratio a marine origin for all traps while the latter suggests this only for the 323 and $1835 \mathrm{~m}$ samples. For the 3 intermediate traps, ribose + fucose values are intermediate between marine and terrestrial. Thus, the high glucose contents found are presumably due to input of reserve material of marine origin.

\section{Chlorophyll pigment fluxes}

As mentioned above, total chlorophyll fluxes decreased constantly with depth. Significant differences were, however, found in pigment composition between individual traps (Table 4). In all samples, acidic compounds (phaeophorbide a and chlorophyll $c$ derived components among others) account for the majority of pigment flux. These compounds will not be further distinguished here since Brereton \& Keeley (1986) reported problems with positive identification of phaeophorbide $a$.

Unknown compounds, most likely chlorophylla degradation products (R.F.C. Mantoura pers. comm. 1985), increased from 323 to $539 \mathrm{~m}$ at the expenş of phaeophytin $a$. The latter increased again towards the deeper traps. Phaeophytin $b$ showed a continuous increase with depth.

Chlorophyll $b$ is an uncommon pigment in phytoplankton with a restricted occurrence in Chlorophyceae and Prasinophyceae (Parsons et al. 1977). Since as yet unidentified green flagellates were found in the upper water column during trap deployment (von Bodungen 1986) these are most probably responsible for the presence of the small amounts of phaeophytin $b$ in the shallower traps. There is no feasible mechanism by which planktonic material leaving the euphotic zone could escape the deeper traps. Thus, the increasing phaeophytin $b$ levels also argue in favour of a second source of sedimenting material.

Although the HPLC technique employed allowed determination of phaeopigments only, a comparison between these results and the spectrophotometric analyses can nevertheless be made. A weight conversion factor from chlorophyll equivalents to phaeopigments of $0.45 \pm 0.07$ (SD) is obtained. This compares favourably with values of 0.39 for phaeophytin $a$ and 0.47 for phaeophorbide a given by Dawson et al. (1985).

\section{Source considerations}

From the data presented above, significant differences between shallow and deeper traps are obvious. This appears not to be restricted to the present time frame since Liebezeit (1984) and Liebezeit \& Bölter (1986) reported for the austral summer 1980 that both carbohydrate and amino acids had different spectra in euphotic and aphotic zone samples. These authors already speculated on an origin of deep water suspended material other than the euphotic zone of the stations in question.

If differences in chemical composition between traps were due to horizontal transport of sinking planktonic material produced somewhere else, one would nevertheless expect a planktonic biochemical signal in all traps, e.g. in the ASP/GLY or mannose/xylose ratios, even with a different species composition. This is, however, not the case.

The points discussed above argue in favour of a second source of sedimenting matter which is not planktonic in origin. Here, terrestrial or macroalgal material might give rise to the observed differences in organic matter composition. Terrestrial material introduced into the Antarctic marine environment by e.g. soil erosion has not been found to contribute significantly to sedimentary organic matter in the Bransfield Strait whereas Weddell Sea sediments contain a high proportion from this source (Müller et al. unpubl.). Similarly, the presence of a large contribution from chlorophyll $b$ argues against a major flux of eroded material since the aldehyde moiety of this compound is rapidly reduced during early diagenesis and hence cannot be expected to be present in soils of Mesozoic age in the Antarctic.

Macroalgae are abundant in shallow waters of the Bransfield Strait (e.g. Dieckmann et al. 1984). From $\delta^{13} \mathrm{C}$ analyses of the present sediment trap material, a contribution from this source can be suspected (M. Whiticar pers. comm. 1986). Examination of the chemical data in the light of such a hypothesis strongly argues in favour of a macroalgal input. Neither MaCrocystis integrifolia nor Nereocystis luetkeana contained $\beta$-alanine over the annual growth cycle (Rosell \& Srivastava 1985) thereby explaining the relative decrease of this non-protein amino acid with depth. Laminaran, a $\beta$-1,3-glucan, occurs widely as reserve material in Phaeophyceae and other classes of macroalgae (Percival \& McDowell 1967). Sannié (1950, 1951) found high contents of this storage polysaccharide in both Macrocystis pyrifera and Durvillea antarctica from Kerguelen Island. Thus, the higher glucose content of the deeper samples is in agreement with a macroalgal source.

The presence of relatively high fructose contents in 
all samples (Table 4) also requires some comment. While Quillet $(1954,1957)$ suggested this ketose to be an intermediate product in the formation of mannitol from laminaran via glucose in Laminaria flexicaulis, this mechanism would certainly not give rise to the high values found. Fructosans are also not common storage products of phytoplankton although this sugar was found to be present in minor quantities in hydrolysates of suspended material (e.g. Ittekkot et al. 1982, Liebezeit 1984, see also Mopper et al. 1980). Whereas in shallow water sediments of Kiel Bight the occurrence of small amounts of fructose in the $>63 \mu \mathrm{m}$ fraction has been linked to macroalgae (Liebezeit 1986), in the Lofoten Basin sediment trap experiment (Liebezeit \& Ittekkot unpubl.) high fructose contents appear to be related to terrestrial inputs. Bacteria have been reported to synthesise fructosans as reserve polymers (cf. Eveleigh 1974). Although the presence of $\beta$ alanine suggests a significant bacterial biomass to be present on sinking particles, with the available data a bacterial source of fructose cannot be positively established. Thus, the origin of this monosaccharide needs further elucidation.

Himantothallus grandifolius collected off King George Island in the Bransfield Strait was found to contain chlorophyll $b$ as was Laminaria saccharina from the Brittany coast (Abele \& Liebezeit unpubl. results). Thus, while the small amounts of phaeophytin $b$ in the shallower traps might be the result for a minor contribution from as yet unidentified green flagellates, the increased rclative content in the deeper traps are probably the result of an input from macroalgal material. Wort (1955) as well as Whyte \& Englar $(1975,1978,1980)$ report high phosphorus contents (up to $1.6 \% \mathrm{~d} . \mathrm{wt}$ ) in both Macrocystis integrifolia and $\mathrm{Ne}$ reocystis luetkeana. Thus, the TPP flux data (Table 2) are also in accordance with increasing fluxes from macroalgal sources.

The points discussed above argue in favour of a major contribution from shallow water macroalgae to deep water traps, presumably as a result of downslope transport thereby avoiding the shallower traps. Based on the data of Rosell \& Srivastava (1985), and assuming the $323 \mathrm{~m}$ trap to contain planktonic material only, contributions of macroalgae to total organic flux can be calculated. For this purpose we used a value of 0.97 $( \pm 0.09)$ for the aspartic acid/glycine ratio and zero content of $\beta$-alanine for phaeophycean macroalgae. The ASP/GLY ratio compares well with the value of 1.01 recalculated from the data of Mateus et al. (1976). Application of a linear mixing model results in the relative contributions given in Table 5 . Similar calculations can be made for phaeophytin $b$ and total phosphorus.

The underlying assumption for all the above
Table 5. Estimated relative contributions (\%) from macroalgae to total organic matter flux

\begin{tabular}{|lccccc|}
\hline & \multicolumn{5}{c|}{ Depth (m) } \\
& 323 & 539 & 963 & 1410 & 1835 \\
\hline B-alanine & 0 & 38 & 42 & 96 & 82 \\
Aspartic acid/glycine & 0 & 64 & 85 & 51 & 37 \\
Phaeophytin $b$ & 0 & 14 & 75 & 83 & 86 \\
TPP & 0 & 31 & 63 & 77 & 78 \\
$\bar{X}$ & 0 & 37 & 66 & 77 & 71 \\
\hline
\end{tabular}

estimates is that the compounds in question do not undergo degradation during vertical transport. This is most likely not the case and hence the figures given in Table 5 represent maximum estimates. On the other hand, planktonic material will also be degraded. Therefore, these correction data should be regarded as order of magnitude rather than as absolute figures.

Although there are no standing stock data available for macraalgal populations in the Bransfield Strait, the primary production of about $2000 \mathrm{~g} \mathrm{C} \mathrm{m}^{-2} \mathrm{yr}^{-1}$ as compared to $60 \mathrm{~g} \mathrm{C} \mathrm{m}^{-2} \mathrm{yr}^{-1}$ of planktonic production (W. Reichardt pers. comm. 1986) can easily account for the high macroalgal contributions in the deeper traps.

One of the major problems in applying such data for quantitative purposes is the high variability of macroalgal chemical composition. Thus, both phosphorus and amino acid contents exhibit distinct annual cycles (Wort 1955, Rosell \& Srivastava 1985). In addition, differences in composition between individual parts of macroalgae have also been reported. Macrocystis integrifolia and Nereocystis luetkeana showed higher phosphorus contents in fronds than in stipes (Wort 1955). Liebezeit \& Dawson (1982) reported distinct differences in both reserve and structural polysaccharides in individual parts of calcareous Chlorophyceae.

In view of this high natural variability in chemical composition of macroalgae, the relatively close correspondence of the correction factors presented in Table 5 represents supporting evidence that specific chemical parameters can be used to estimate macroalgal contributions to total organic carbon flux in the Bransfield Strait. These data clearly indicate that, especially in the deeper traps, the majority of vertical carbon flux is composed of macroalgal material.

From the $\mathrm{C} / \mathrm{N}$ ratios the temporal origin of this sedimenting material might be pinpointed. Rosell \& Srivastava (1985) reported significant differences in this ratio between the growing and non-growing seasons, i.e. values around 30 for the former and around 10 for the latter case. Thus, input of material produced in the austral summer should be discernible by increased 
$\mathrm{C} / \mathrm{N}$ ratios. This is, however, not the case (Table 3 ) and it can be assumed that the trapped material is of winter origin which has undergone downslope transport after maceration by ice action. This is supported by field observations of Reichardt (pers. comm. 1986) who noted considerable amounts of shredded macroalgae at King George Island during winter.

Reichardt \& Dieckmann (1984), on the other hand, reported a noticeable decrease in $\mathrm{C} / \mathrm{N}$ ratios of Himantothallus grandifolius from around 30 to 10 during degradation experiments within some $10 \mathrm{~d}$ due to bacterial colonisation. Since the austral summer 1983 was particularly stormy (field observations) this might have led to enhanced erosion of kelp. However, the virtual absence of $\beta$-alanine in the deeper traps argues against an input of summer material heavily colonised by bacteria.

\section{Comparison with other flux estimates}

From compilation of a number of carbon flux data, Suess (1980) derived an empirical equation relating carbon flux at any given depth $>50 \mathrm{~m}$ with euphotic zone productivity. In the following we will compare Bransfield Strait fluxes corrected for macroalgal contributions with those predicted by the Suess equation.

Since primary production increased from about 400 to $1000 \mathrm{mg} \mathrm{C} \mathrm{m}^{-2} \mathrm{~d}^{-1}$ during the time of trap deployment (von Bodungen 1986) these 2 extreme values will be used in the comparison. For the 323,539 and $1835 \mathrm{~m}$ traps there is a remarkably close correspondence between the $1000 \mathrm{mgC}$ estimate and our corrected fluxes (Table 6). This indicates that our initial assump-
Table 6. Comparison of planktonic flux estimates. Fluxes in $\mathrm{mg} C \mathrm{~m}^{-2} \mathrm{~d}^{-1}$

\begin{tabular}{|c|c|c|c|}
\hline \multirow[t]{2}{*}{ Depth $(\mathrm{m})$} & \multirow[t]{2}{*}{ Corrected } & \multicolumn{2}{|c|}{ Suess $(1980)^{\cdots}$} \\
\hline & & $\begin{array}{c}P P=1000 \\
m g C m^{-2} d^{-}\end{array}$ & $\begin{array}{c}\mathrm{PP}=400 \\
\mathrm{mgC} \mathrm{m}^{-2} \mathrm{~d}^{-1}\end{array}$ \\
\hline 323 & 131.9 & 126.6 & 50.6 \\
\hline 539 & 75.8 & 76.7 & 30.7 \\
\hline 963 & 27.3 & 43.2 & 17.3 \\
\hline 1410 & 21.7 & 29.6 & 11.8 \\
\hline 1835 & 24.3 & 22.8 & 9.1 \\
\hline \multicolumn{4}{|c|}{$\begin{array}{l}\text { - Total flux corrected for macroalgal contributions with } \\
\text { mean values from Table } 5 \\
\text { - Flux estimated employing the equation given by Suess } \\
\text { (1980) with primary production (PP) data from von } \\
\text { Bodungen (1986) }\end{array}$} \\
\hline
\end{tabular}

tion for quantification of macroalgal contributions, i.e. an exclusive planktonic origin of the $323 \mathrm{~m}$ trap material, is valid. It furthermore shows that the high production period contributes mainly to vertical flux.

The 963 and $1410 \mathrm{~m}$ fluxes are underestimated by the correction applied for macroalgal input. The deviations from the fluxes calculated with the Suess equation are, however, within the range covered by the individual correction factors of Table 5. It should also be pointed out that there are a number of processes operating in the water column which can explain the differences between the 2 flux estimates: (1) krill pellets which were the main agent in transporting planktonic material did not reach the deeper traps due to either disintegration and subsequent retardation in sinking or to horizontal displacement due to strong

Table 7. Carbohydrate composition of sediments with different organic matter sources. M: macroalgal; P: planktonic; T: terrestrial. Data for Kiel Bight from Liebezeit (1986), all other are unpublished results

\begin{tabular}{|c|c|c|c|c|c|c|c|}
\hline \multirow[b]{2}{*}{ Carbohydrate } & \multirow[b]{2}{*}{$M$} & \multirow[b]{2}{*}{ M } & \multicolumn{2}{|c|}{ Dominant source } & \multirow[b]{2}{*}{$P$} & \multirow[b]{2}{*}{$\mathrm{T}$} & \\
\hline & & & M & M & & & \\
\hline Glucose & 7.3 & 4.8 & 25.5 & 9.7 & 13.6 & 41.3 & \\
\hline Galactose & 15.0 & 16.1 & 14.5 & 23.0 & 17.5 & 8.5 & \\
\hline Mannose & 3.3 & 6.4 & 11.0 & 17.0 & 17.3 & 1.2 & \\
\hline Fructose & 1.1 & 0.2 & - & - & 0.4 & - & \\
\hline Arabinose & 6.8 & 11.3 & 9.9 & 11.8 & 10.1 & 5.8 & $\mathrm{~mol} \%$ \\
\hline Ribose ${ }^{\cdot}$ & 9.1 & 17.9 & 13.7 & 8.1 & 7.9 & 10.9 & $\mathrm{~mol} \%$ \\
\hline Xylose & 7.2 & 16.4 & 12.3 & 15.2 & 15.1 & 12.6 & \\
\hline Fucose & 25.1 & 16.5 & 10.7 & 11.8 & 8.9 & 4.7 & \\
\hline 2-deoxyribose & 4.4 & 3.8 & 3.4 & 1.6 & 2.8 & 9.9 & \\
\hline Unknown & 7.8 & 6.2 & 2.4 & 1.8 & 6.4 & 5.2 & \\
\hline Location & \multicolumn{2}{|c|}{ Bransfield Strait } & \multicolumn{2}{|c|}{ Kiel Bight } & Off NW Africa & Weddell Sea & \\
\hline Water depth (m) & 100 & 923 & 28 & 28 & 2575 & 3791 & \\
\hline Sediment depth $(\mathrm{cm})$ & $0-5$ & $0-5$ & $0-1$ & $9-10$ & $2-10$ & $0-0.5$ & \\
\hline
\end{tabular}


currents at depth; and (2) repackaging of disintegrated krill faecal material by deeper living zooplankton could lead to an avoidance of the intermediate traps due to vertical migration. This is to some extent supported by the microscopic analyses of Gersonde \& Wefer (1986).

\section{Effects on sedimentary organic matter}

The data presented above demonstrate that shallow water macroalgae contribute significantly to the vertical flux of organic matter in the Bransfield Strait. Since this contribution manifests itself mainly in the form of easily degradable compounds such as chlorophyll $b$ or laminaran it cannot be expected a priori to also establish this particular source in the sedimentary record.

Examination of sedimentary chlorophyll derivatives shows only traces of chlorophyll $b$ derived compounds to be present (Liebezeit unpubl.). Carbohydrate spectra are, however, clearly affected by the type of organic material being deposited (Table 7). There are significant differences in relative glucose and fucose contents between sedimentary organic matter of predominantly planktonic, macroalgal and terrestrial origin. Glucose appears to be present mainly as reserve compound in the macroalgal material as is evident from the decrease with water depth in the Bransfield Strait and the differences between samples from within and below the bioturbated zone in Kiel Bight sediments.

Although the data base at present is too small to put this assumption on a firm basis it seems that macroalgae not only contribute to the metabolic requirements of a deep water benthic detritus consuming community but also may leave a noticeable imprint on the sedimentary record.

Acknowledgements. Part of this work was carned out while GL held a research fellowship of the Deutsche Forschungsgemeinschaft (Li 352/1) at the Organic Geochemistry Unit, University of Bristol, U.K. We are indebted to G. Wefer for help with the sediment traps and to $M$. Sternhagen for carrying out the carbohydrate analyses.

\section{LITERATURE CITED}

Berner, R. A. (1982). Burial of organic carbon and pyrite sulfur in the modern ocean and its geochemical and environmental significance. Am. J. Sci. 282: 451-473

Bodungen, B. von (1975). Der Jahresgang der Nährsalze und der Primärproduktion des Plankton in der Kieler Bucht unter Berücksichtigung der Hydrographie. Ph.D. thesis, Kiel University

Bodungen, B. von (1986). Phytoplankton growth and krill grazing during spring in the Bransfield Strait, Antarctica.
Implications from sediment trap collections. Polar Biol. (in press)

Bodungen, B. von, Smetacek, V. S., Tilzer, M. M., Zeitzschel, B. (1986). Primary production and sedimentation during spring in the Antarctic Peninsula region. Deep Sea Res. 33: $177-194$

Brereton, R. G., Keeley, B. J. (1986). Early chlorin and bacteriochlorin diagenesis in recent aquatic sediments. Adv. org. Geochem. 1985

Cole, J. J., Honjo, S., Caraco, N. (1985). Seasonal variation in the flux of algal pigments to a deep-water site in the Panama Basin. Hydrobiologia 122: 193-197

Cowie, G. L., Hedges, J. I. (1984). Carbohydrate sources in a coastal marine environment. Geochim. Cosmochim. Acta 48: 2075-2087

Dawson, R., Liebezeit, G. (1983). Determination of amino acids and carbohydrates. In: Grasshoff, K., Kremling, K., Ehrhardt, M. (ed.) Methods of seawater analysis. Verlag Chemie, Weinheim, p. 319-340

Dawson, R., Kalbfleisch, J., Liebezeit, G., Llewellyn, C. A. Mantoura, R. F. C., Moreau, F., Poulet, S. A. (1985). HPLC analyses of dissolved free amino acids, pigments and vitamins in plankton and particles. Oceanis 11: 521-531

Degens, E. T., Ittekkot, V. (1985). Particulate organic carbonAn overview. Mitt. Geol.-Paläontol. Inst. Univ. Hamburg, SCOPE/UNEP Sonderband, 58: 7-27

Degens, E. T., Mopper, K. (1976). Factors controlling the distribution and early diagenesis of organic material in marine sediments. In: Riley, J. P., Chester, R. (ed.) Chemical oceanography, Vol. 6, 2nd edn. Academic Press, London, p. 60-113

Dieckmann, G., Reichardt, W., Zieliński, K. (1984). Growth and production of the seaweed, Himantothallus grandifolius, at King George Island. In: Siegfried, W. R., Condy, P. R., Laws, R. M. (ed.) Antarctic nutrient cycles and food webs. Springer Verlag, Berlin, p. 104-108

Edler, L. (1979). Recommendation on methods for marine biological studies in the Baltic Sea: phytoplankton and chlorophyll. The Baltic Marine Biologists Publ. 5: 1-38

Eveleigh, D. E. (1974). Microbial monosaccharides and polysaccharides. In: Laskin, A. E., Lechevalier, H. A. (ed.) Handbook of microbiology, condensed ed. CRC Press, Cleveland, p. 674-731

Gersonde, R., Wefer, G. (1987). Sedimentation of biogenic siliceous particles in Antarctic waters (Atlantic sector). Mar. Micropaleontol. 11 (in press)

Grasshoff, K. (ed.) (1976). Methods of seawater analysis. Verlag Chemie, Weinheim

Honjo, S., Manganini, S. J., Cole, J. J. (1982). Sedimentation of biogenic matter in the deep ocean. Deep Sea Res. 29 609-625

Ittekkot, V., Degens, E. T., Brockmann, U. (1982). Monosaccharide composition of acid-hydrolyzable carbohydrates in particulate matter during a plankton bloom. Limnol. Oceanogr. 27: 770-776

Ittekkot, V., Deuser, W. G., Degens, E. T. (1984a). Seasonality in the fluxes of sugars, amino acids, and amino sugars to the deep ocean: Sargasso Sea. Deep Sea Res. 31: $1057-1069$

Ittekkot, V., Degens, E. T., Honojo, S. (1984b). Seasonality in the fluxes of sugars, amino acids, and amino sugars to the deep ocean: Panama Basin. Deep Sea Res. 31: 1071-1083

Knauer, G. A., Martin, J. H., Bruland, K. W. (1979). Fluxes of particulate carbon, nitrogen, and phosphorus in the upper water column of the northeast Pacific. Deep Sea Res. 26: $97-108$

Lee, C., Cronin, C. (1982). The vertical flux of particulate 
organic nitrogen in the sea: decomposition of amino acids in the Peru Upwelling area and the equatorial Atlantic. J. mar. Res. 40: 227-251

Lee, C., Cronin, C. (1984). Particulate amino acids in the sea: effects of primary productivity and biological decomposition. J. mar. Res. 42: 1075-1097

Liebezeit, G. (1980). Chlorophyll a in marine phytoplankton: Separation by HPLC and specific fluorimetric detection. J. High Resolut. Chromatogr. Chromatogr. Commun. 3: $531-533$

Liebezeit, G. (1984). Particulate carbohydrates in relation to phytoplankton in the euphotic zone of the Bransfield Strait. Polar Biol. 2: 225-228

Liebezeit, G. (1985). Residual amino acid fluxes in the upper water column of the Bransfield Strait. Oceanol. Acta 8: $59-65$

Liebezeit, G. (1986). Pelagic and benthic sources of sedimentary carbohydrates in a shallow water environment - Kiel Bight, Baltic. Mar. Geol. 71: 201-213

Liebezeit, G. (in press). Particulate carbohydrate flux in the Bransfield Strait and the Drake Passage. Mar. Chem.

Liebezeit, G., Bölter, M. (1986). Distribution of particulate amino acids in the Bransfield Strait. Polar Biol. 5: 199-206

Liebezeit, G., Dawson, R. (1982). Changes in the polysaccharide matrix of calcareous green algae during growth Actualités de biochimie marine Vol. 5, Publ. CNEXO (Actes Colloq.) No. 14: 147-154

Liebezeit, G., Schumann, M., Bohde, F. (1985). Residual amino acid fluxes in Kiel Bight - February to June 1980 Mar. Ecol. Prog. Ser. 27: 203-207

Lindroth, P., Mopper, K. (1979). High performance liquid chromatographic determination of subpicomole amounts of amino acids by precolumn fluorescence derivatization with o-phthalaldehyde. Analyt. Chem. 51: 1667-1674

Lorenzen, C. J. (1967). Determination of chlorophyll and pheopigments: spectrophotometric measurements. Limnol. Oceanogr. 12: 343-346

Lorenzen, C. J., Shuman, F. R., Bennett, J. T. (1981). In-situ calibration of a sediment trap. Limnol. Oceanogr. 26: $580-585$

Lorenzen, C. J., Welschmeyer, N. A., Gopping, A. E. (1983). Particulate organic carbon flux in the subarctic Pacific Deep Sea Res. 30: 639-643

Mateus, H., Regenstein, J. M., Baker, R. C. (1976). The amino acid composition of the marine brown alga Macrocystis pyrifera from Baja California. Botanica mar. 19: 155-156

Mopper, K., Dawson, R., Liebezeit, G., Ittekkot, V. (1980). The monosaccharide spectra of natural waters. Mar. Chem. 10: 55-66

Parsons, T. R., Takahashi, M., Hargrave, B. (1977). Biological oceanographic processes. Pergamon Press, Oxford

Peinert, R., Saure, A., Stegmann, P., Stienen, C., Haardt, H. Smetacek, V. (1982). Dynamics of primary production and sedimentation in a coastal ecosystem. Neth. J. Sea Res. 16 $276-289$

Percival, E., McDowell, R. H. (1967). Chemistry and enzymology of marine algal polysaccharides. Academic Press London

Quillet, M. (1954). Sur le métabolisme glucidique des Algues brunes. Présence de fructose chez Laminaria flexicaulis en survie dans l'eau de mer chloroformée. C. r. hebd Séanc. Acad. Sci. Paris 238: 926-928

Quillet, M. (1957). Volémitol et mannitol chez les Phéophycées. Bull. Iab. marit. Dinard 43: 119-124

Reichardt, W., Dieckmann, G. (1984). Kinetics and trophic role of bacterial degradation of macroalgae in Antarctic coastal waters. In: Siegfried, W. R., Condy, P. R., Laws, R. M. (ed.) Antarctic nutrient cycles and food webs. Springer Verlag, Berlin, p. 115-122

Rosell, K.-G., Srivastava, L. M. (1985). Seasonal variations in total nitrogen, carbon and amino acids in Macrocystis integrifolia and Nereocystis luetkeana (Phaeophyta). J. Phycol. 21: 304-309

Sakshaug, E., Holm-Hansen, O. (1984). Factors governing pelagic production in polar oceans. In: Holm-Hansen, $O$., Bolis, L., Gilles, R. (ed.) Marine phytoplankton and productivity. Springer Verlag, Berlin (Lecture Notes Coast. Estuar. Stud. 8: 1-18)

Sannié, C. (1950). Sur la composition d'une algue des îles Kerquelen, Macrocystis pyrifera (1.) Ag. C. r. hebd. Séanc. Acad. Sci. Paris 231: 874-876

Sannié, C. (1951). Sur la composition des algues des îles Kerguelen, Macrocystis pyrifera (1.) Ag. et Durvillea antarctica (Cham) Hariot. C. r. hebd. Séanc. Acad. Sci., Paris 232: 2040-2041

Smetacek, V., Bodungen, B. von, Knoppers, B., Peinert, R., Pollehne, F., Stegmann, P., Zeitzschel, B. (1984). Seasonal stages characterizing the annual cycle of an inshore pelagic system. Rapp. P.-v. Réun. Cons. int. Explor. Mer 183: $126-135$

Suess, E. (1980). Particulate organic carbon in the oceans: surface productivity and oxygen utilization. Nature, Lond. 288: $260-263$

Staresinic, N. (1980). The vertical flux of particulate organic matter in the Peru coastal upwelling as measured with a free-drifting sediment trap. Ph.D. thesis, Woods Hole Oceanogr. Inst./Massachussets Inst. Technol.

Wefer, G., Suess, E., Balzer, W., Liebezeit, G., Müller, P. J., Ungerer, C. A., Zenk, W. (1982). Fluxes of biogenic compounds from sediment trap deployment in circumpolar waters of the Drake Passage. Nature, Lond. 299: 145-147

Whyte, J. N. C., Englar, J. R. (1975). Composition of nonmetallic inorganic components of the marine alga Nereocystis luetkeana over the growing season. Tech. Rep. Fish. Mar. Serv, (Canada) 568: 1-34

Whyte, J. N. C., Englar, J. R. (1978). Seasonal changes in the content of nonmetallic inorganic components in the marine alga Macrocystis pyrifera. Tech. Rep. Fish. Mar. Serv. (Canada) 765: 1-26

Whyte, J. N. C., Englar, J. R. (1980). Seasonal variation in the inorganic constituents in the marine alga Nereocystis luetkeana. Part II, non-metallic elements. Botanica mar 23: $19-24$

Wort, D. J. (1955). The seasonal variation in chemical composition of Macrocystis integrifolia and Nereocystis luetkeana in British Columbia coastal waters. Can. J. Bot. 33 $323-340$

Zeitzschel, B., Uhlmann, L., Diekmann, P. (1978). A new multi-sample sediment trap. Mar. Biol. 45: 285-288 